birds. He intersperses his scientific descriptions with anecdotes, sometimes amusing, as of those of the hawk and the eagle, the parrot, and the wren. Turning to fishes, he first refers to some of the physical properties of water and then describes the inhabitants of the deep with a story about the plaice: fishes finished, he describes minerals, with an interesting account of the properties of the loadstone, and vegetables: and then the animal kingdom, with amusing stories about weasels, monkeys and lions : and finally comes to the 'lord of creation', man; after a talk of light and mirrors, he describes the purports of the farm-yard and the dwelling house, with an interesting discussion on silk-worms, and incidentally mentions education and the universities of his day.

\section{British Association: Officers for 1937}

THe annual meeting of the British Association will be held next year in Nottingham on September 1-8 under the presidency of Sir Edward Poulton. The following sectional presidents have been appointed : Section A (Mathematical and Physical Sciences), Dr. G. W. C. Kaye; B (Chemistry), Dr. F. L. Pyman; C (Geology), Prof. L. J. Wills; D (Zoology), Prof. F. A. E. Crew ; E (Geography), Prof. C. B. Fawcett ; F (Economics), Prof. P. Sargant Florence; G (Engineering), Sir Alexander Gibb; H (Anthropology), Dr. J. H. Hutton ; I (Physiology), Dr. E. P. Poulton; J (Psychology), Dr. Mary Collins; K (Botany), Prof. E. J. Salisbury; I. (Education), Mr. H. G. Wells; M (Agriculture), Mr. J. M. Caie.

\section{Peking Man: Further Discoveries}

REcent excavation in the cave of Choukoutien, the home of Peking man, has proved fortunate beyond all expectation. No less than three new skulls of Sinanthropus have been added to the relies of this primitive type of early man. On October 22, $\mathrm{Mr}$. I. P. Chia, of the National Geological Survey of China, brought to light a left mandible with teeth pronounced to be male in type, to which Sir Grafton Elliot Smith refers in a letter to The Times of December 5 . This was followed by the discovery by the same excavator of two skulls (The Times, Nov. 20) and to this in turn has succeeded a further discovery of another skull, which, if the description given in the dispatch from the Peiping correspondent of The Times of December 8 be accepted as accurate, may well prove of even greater significance than the earlier finds of new material. With the two skulls previously known, of which the first was found by Mr. W. C. Pei in December 1929, there are now five skulls of Sinanthropus pekinensis in existence, while a sixth has been reconstructed from fragmentary finds by Prof. Franz Weidenreich, the director of the Cænozoic Research Laboratory of the Geological Survey. The new material is of outstanding importance in view of the fact that the skulls are those of fully developed adults, whereas the two skulls previously known were those of adolescents. Of the skulls recently dis. covered, the first two are of a male and a female, in age between forty and fifty years. Added evidential value attaches to the third skull owing to the fact that it is in a more complete state of preservation than any previous specimen. Certain parts of the base of the skull missing in the other skulls are here present, as well as parts of the facial skeleton and nasal structure.

\section{Significance of Peking Man}

THe relies of Peking man available for study at the Peiping Union Medical College, together with the new skulls, represent twenty-four individuals, and include twelve lower jaws and nearly one hundred teeth. They fully justify the description of them by Prof. Weidenreich as the "richest and most complete collection of human fossils ever recorded, unique in every respect" (The Times, Nov. 25). Since Prof. Weidenreich's appointment to the Rockefeller Insti. tute, constituting him Director of the Cænozoic Research Laboratory in succession to the late Dr. Davidson Black-an appointment made on the recommendation of Sir Grafton Elliot Smith, as the latter now reveals in his letter to The Times. where, however, by a clerical error the name appears as "Weideman"- he has naturally devoted much time and attention to the study of Peking man, and in a recent publication (see NATuRE, 173, 73) has put forward some interesting and suggestive conclusions as to the relation between Sinanthropus and Mongolian man, while further important results have accrued from his comparative studies based more particularly on the examination of the endocranial casts (NATURE, Oct. 17, p. 689). With this additional important material at his disposal, illuminating studies may be anticipated. While it is too early, and too little information is available, to attempt any forecast of the direction in which results are likely to tend, it is interesting to note that it is stated that the female skull has many similarities to Pithecanthropus, while the male skull is much higher and nearer Neanderthal man. Further, Prof. Weidenreich is reported to have said that the various specimens of Peking man form links between Pithe. canthropus and Neanderthal man. Sir Grafton Elliot Smith's letter to The Times, relying on information supplied by Mr. W. C. Pei, now superseded, expresses some anxiety as to the future of these investigations. Clearly, in view of the importance of the material now awaiting examination, any serious interruption or even break in continuity would be a catastrophe.

\section{British Launderers' Research Association}

Extensions to the laboratories of the British Launderers' Research Association were opened by Sir William Bragg on December I. Mr. W. H. Markham, chairman of the Association, mentioned, in his introductory remarks, that the recent extension of the basis of membership of the Association has met with a good response from the industry, and also that, with an increase of the maximum grant received from the Department of Scientific and Industrial Research, the income of the Association in the

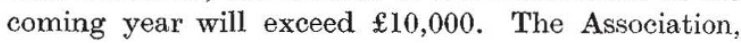

